\title{
Diffusion of ideas in the era of the Belt and Road: Insights from China-CEE think tank cooperation
}

\author{
Anastas Vangeli ${ }^{1}$ (D) \\ Published online: 10 September 2019 \\ (C) The Author(s) 2019
}

\begin{abstract}
To address part of the puzzle on China's ideational impact in the era of the Belt and Road Initiative (BRI), the article studies social interaction of Chinese and CEE think tanks by employing the concept of diffusion of ideas. The article proposes a theoretical framework to study diffusion inspired by reflexive social science that focuses on frames, (geoeconomic) imaginaries, and translations. The asymmetrical interaction of think tanks led to aligning the frames of the different actors and producing a context of peaceful and pragmatic cooperation, extension of the geoeconomic imaginaries to include previously unorthodox positions, and translation of policy concepts that are localized in accord with the dispositions of the CEE actors involved. Nevertheless, the China-CEE think tank cooperation, when analyzed in a broader context, has relatively limited impact on societal and policy levels, and is increasingly challenged by actors with greater leverage in the region. What sustain the diffusion of ideas are the potent narratives of imagined futures of prosperity under the New Silk Roads.
\end{abstract}

\section{Introduction}

The power of China to affect how political, economic, and business elites around the world think about economic and political development has always intrigued social scientists. While some of the leading approaches so far have relied on auxiliary concepts such as the Beijing Consensus (Li et al. 2010) or the China Model (Breslin 2011) to explain China's (potential) ideational impact, in the last few years, scholars have increasingly focused on the Belt and Road Initiative (BRI) - an endeavor with particular normative grounding centered on the principles of China's own mode of development (Vangeli 2018a). The BRI has advanced by extending and deepening linkages of all sorts (Andornino 2017) and socializing thousands of individuals that come from various parts of the world, at all levels of the political and social hierarchies,

Anastas Vangeli

avangeli@sns.edu.pl

1 Graduate School for Social Research, Institute of Philosophy and Sociology, Polish Academy of Sciences, Warsaw, Poland 
and across various fields of practice. The rapid development of China-led platforms for interaction under the BRI framework (and beyond) has thus enabled researchers to think beyond the limits of widespread concepts such as soft power (Lukes 2007) or "Chinese influence." To address the ideational impact taking place through China-led diplomatic endeavors, potential or actual, authors have so far employed relational approaches (Kavalski 2013), discussed knowledge (co-)production (Benabdallah 2017), symbolic power (Vangeli 2018b), and principle diffusion (Vangeli 2019).

The agency of the "other" non-Chinese participants in the interactions under the BRI framework is of particular importance when studying the ideational impact from the perspective of the China-led social interactions that proliferate under the BRI. While Chinese leaders traced the contours of the BRI in the period 2013-2018, ${ }^{2}$ it has continued to gradually shape up through the dialogical processes of "co-production" of meanings (Mayer 2017, p. 21). Under the BRI framework, these dialogical processes have involved thousands of politicians, economists, engineers, cultural workers, and, in particular, scholars from both China and its partner countries engaged through BRI. These processes are asymmetrical, in the sense that Chinese actors convene and manage the interaction. However, the non-Chinese actors exercise their agency in the process rather than serving as mere extras.

This article studies the social interaction of knowledge actors - in particular, think tanks - in a China-led setup in one region where the BRI unfolds - that is, the CentralEast (and Southeast) Europe (CESEE, or as the majority of the literature refers to it, $\mathrm{CEE}$ ). In CEE, China has established the platform 16+1 (see Introduction to this issue), which has served to streamline, upgrade, and intensify the interactions between Beijing and the sixteen countries in the region under a pragmatic economic pretext, coordinate involvement of the sixteen countries in the BRI (Vangeli 2017), and provide the communication infrastructure that facilitates the processes of co-production of meanings. The cooperation of Chinese and CEE think tanks has been one of the most visible and productive aspects of $16+1$.

This article tackles the question of impact by employing the concept of diffusion. Policy ideas pertaining to economic development are consistently on the move: they diffuse across national borders, on the various levels of hierarchy, and across different fields of practice. The BRI enables processes of diffusion of ideas with China at the center (Vangeli 2019). Diffusion has been studied from a number of theoretical and methodological perspectives. ${ }^{3}$ This research adopts a reflexivist perspective on diffusion, starting from the premise that diffusion does not take the form of automatized linear transmission of ideas from point A (China) to point B (CEE) (Stone 2013, p. 114), but one of a rather fuzzy process of social interaction in which the reasoning of the adopting actors does not necessarily follow

\footnotetext{
${ }^{1}$ Influence is a "symbolic medium of persuasion" (Parsons 1963, p. 38). Ideational impact is a broader term, referring to ideational change as a consequence of a particular stimulus, which does not necessarily have to take the form of persuasion. Contextual changes, social performances, external events, embodied experiences, and other social and natural phenomena can all have a particular ideational impact.

${ }^{2}$ By the Second Belt and Road Forum in April 2019, it was announced that the Chinese leadership will take measures to provide more concise definitions of BRI, which may affect the process of (co-)production of meanings in the future.

${ }^{3}$ For a review of the study of diffusion, see Dobbin et al. (2007) and Gilardi (2013).
} 
particular patterns or common sense. While this article focuses on the diffusion of policy ideas among knowledge actors and epistemic communities, the question of how these actors and epistemic communities have influenced policy outcomes is left for future research.

In terms of the conceptualization of diffusion, the approach developed here is similar to the "bounded rationality" theory of diffusion (Weyland 2009), transcending rational choice models, which posits that imperfect information flows and biased reasoning facilitates the adoption of new ideas. Yet, while the claim that diffusion of ideas takes place through such imperfect reasoning is of particular significance, it can be further advanced by taking into account Bourdieu's critique of bounded rationality as a concept that overly economizes the human brain and ignores the rootedness of people's calculations in their social context (Swedberg 2011, p. 12).

The application of three reflexivist concepts - frames, imaginaries, and translations - serves to disaggregate the process of diffusion into different elements for the purpose of analyzing ideational diffusion in the context of the social interactions that shape it. The alignment of frames is a prerequisite for diffusion to take place; the extension of existing imaginaries also extends the normative reference systems, while the innovations in these systems are then localized through processes of translation. This theoretical framework thus facilitates the exploration of both the agency of the actors involved and the social structural factors that shape their context, while ultimately focusing on the processes of interactions that constitute diffusion.

Think tanks are knowledge actors that play a significant role in processes of ideational diffusion. Their role in transnational diffusion is amplified through knowledge networks, defined as "system[s] of coordinated research, results dissemination and publication, intellectual exchange, and financing across national boundaries" (Stone 2013, p. 43). By looking at think tanks and their networks as "catalysts" (McGann 2010) of various diffusion processes, scholars have studied democratization and liberalization in post-socialist countries (Scott 1999; Krastev 1999); globalization and the advance of neoliberalism (Ladi 2000; Plehwe et al. 2007); regional cooperation (Capie 2010) and European integration (Barani and Sciortino 2011). The understanding of China-led diffusion in the era of the BRI can, in a similar vein, be advanced by a study of the work of think tanks as actors and their catalytic interactions.

Empirically, the article builds upon the author's long-standing experience of cooperation with think tanks in CEE, China, and beyond and a research design incorporating three key components: (a) participant observation during the period 2014-2018 in official China-CEE think tank cooperation events in China and CEE, as well as other relevant events that took place in China, CEE, and beyond; (b) field research in Beijing, Warsaw, Budapest, Prague, Belgrade, and Skopje that included interviews with Chinese and CEE think tank scholars; and (c) analysis of think tank reports, secondary literature, and other relevant textual data.

In the following section, the article develops a framework for analyzing ideational diffusion. Then, it presents the actors and their contexts - these are the Chinese and CEE think tanks - after which it discusses their social interactions and analyzes diffusion of ideas in the context of those interactions. 


\section{The diffusion process}

In this section, I focus on three subprocesses that facilitate the diffusion process in the China-led multilateral formats: alignment of frames, extension of (geoeconomic) imaginaries, and translation of policy concepts. These three subprocesses are interconnected and interdependent, though tying them together should not be seen as a formulation of a definite theory of diffusion, but rather as an attempt to grasp only one part of the greater puzzle that diffusion resembles.

Frames are "normative and sometimes cognitive ideas that are located in the foreground of policy debates" (Campbell 2002, p. 26) that help make certain actions and policies acceptable to others. Having shared, or rather mutually "aligned" frames, is a prerequisite for ideas to diffuse (Béland 2009). Given the power asymmetry of the China-led setups, the frames provided by Chinese actors are dominant, propelled by symbolic power (Vangeli 2018b), that is the "power to construct reality which tends to establish a gnoseological order [...] which makes agreement possible between intelligences" (Bourdieu 1979, p. 79). The frame alignment in the China-led formats for discussion is thus an asymmetrical process. But non-Chinese actors have their own agency in the way dominant frames are localized, which can potentially lead to unintended consequences. ${ }^{4}$

Imaginaries are sets of ideas that help "people 'imagine' their social surroundings" but also the way the world should or could look like (Taylor 2002, p. 106). Of particular significance for the BRI are the imaginaries that help make sense of one's own role in the global economy, but also create a vision for the future trajectory of national development which charts actions in the present. The notion of such geoeconomic imaginary does not imply an absolute consensus nor a uniform way of thinking but rather a broader set of possible pathways of thinking and practice. Through the interactions within China-led formats, the "universe of what is thinkable, sayable and [potentially accepted] as a legitimate" (Vangeli 2018b, p. 677) viewpoint in terms of economic development gets expanded to include novel, or previously "impossible" positions, often based on geoeconomic fiction (Beckert 2016). ${ }^{5}$ Imaginaries are thus normative in nature, but they are non-theoretical, as they are based on "images, stories, and legends" (Taylor 2002, p. 106). Nevertheless, they inspire theorization and conceptual thinking, as actors need to provide answers on how to reach those imagined, fictional outcomes. The grander these outcomes, the more complex theorization they require.

When thinking about how to achieve those outcomes, actors come up with discursive constructs that serve as "general guidelines for designing programs or institutions," that (Weyland 2009, p. 8) call policy principles, which provide a theoretical backing to the loosely defined imaginaries. The actors formulate these principles through dialog which "entails representing something in a new way and in a new place, inevitably changing what it means" (Lendvai and Stubbs 2007, pp. 175-177). This (sub)process that involves the creation of new meanings, their dissemination, and finally their localization can be summarized as diffusion-as-translation. In practice, translation of policy concepts "is not a single event or unified sequence of exchanges" but rather "on-

\footnotetext{
${ }^{4}$ Some of the unintended consequences are elaborated on by Kavalski in this issue.

${ }^{5}$ The term fiction is not used in the sense that it is wrong, but that is simply a product of imagination.
} 
going process of international visitors of experts, collaborations and conferences, funding of publications as well as happenstance meetings and sharing of information, whereby new orthodoxies are both incrementally picked up in public discourse and deliberately propelled to policy circles" (Stone 2013, p. 113).

\section{Chinese think tanks and the BRI}

Think tanks have historically formed an important part of China's policy landscape. As knowledge actors contributing to the vibrant process of foreign policy discussion (Li 2017; Zhu 2017; Menegazzi 2017), they have received particularly significant impetus under the rule of Xi Jinping. During the 18th Party Congress in 2012, the Party Report called for increasing the role of think tanks in policy-making. With the Thirteenth Five-Year Plan (2016-2020), China announced the establishment of 50-100 "high-end think tanks."

Compared to their Western (and CEE) counterparts, Chinese think tanks are more firmly embedded in the national political field. As knowledge production actors, they do not work in isolation from foreign policy implementers, but closely cooperate with them using various channels (Zhao 2006; Shambaugh 2013). In this vein, the input of think tanks and intellectuals has been instrumental in advancing the BRI since its onset. The so-called think tank fever (zhikure) (Li 2017, p. 5) and the BRI fever have coincided, with think tanks continuously invited by the government to take an active role in BRI (Cao 2019). Think tanks have contributed to the articulation of the BRI vision and provided specific suggestions and policy proposals in order to make it more effective and appealing to their foreign counterparts. They have been also pivotal in filling the gaps in Chinese policymakers' knowledge of various parts of the world. Tying its fate together with a number of countries and regions around the world, China now needs area expertise in the geographic areas covered by BRI. Hence, BRI-focused think tanks, research projects, and partnerships are mushrooming, impacting the field of knowledge production in China (Mayer 2017, p. 3), and the political field as well (Yu 2018, p. 230).

Chinese think thanks have been particularly active in establishing new linkages with their counterparts from the partner countries under the BRI (Li and Wong 2018). They have also become pro-active in establishing and initiating think tank networks and associations - not only in CEE. The summits of China-led multilateral platforms, such as those in Africa and Latin America, are accompanied by exchanges between Chinese think tanks with their foreign counterparts (China-CELAC Forum 2015; Emewu 2018). Chinese think tanks have also established platforms on the global level, such as the Silk Road Think Tank Association or Silk Road Think Tank Network (SiLKS). In doing so, they have not only needed to expand their area expertise on the various regions of the world, but also to adapt to having policy dialogs in diverse contexts.

\section{Chinese think tanks working on CEE}

In the period 1989-2010, only a handful of Chinese scholars studied CEE, which has led to a rather poor understanding of CEE in China. ${ }^{6}$ Today, a number of leading think

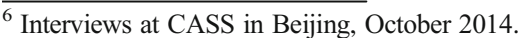


tanks, as well as other knowledge actors, have dedicated teams and units that conduct research, publish, and host events on CEE and China-CEE relations with contributions from their CEE counterparts, with the goal to fill significant knowledge gaps on the region. Chinese universities have also started teaching the CEE languages, training new generations of Chinese area experts on CEE. ${ }^{7}$

The central knowledge actor that studies and establishes linkages with CEE is the Chinese Academy of Social Sciences (CASS), the largest government-affiliated think tank. CASS houses both a Department of CEE Studies within the Institute for European Studies (IES) and researchers working on CEE in the Institute for East European, Russian and Central Asia Studies (IEERCAS). It has launched the China-CEE Institute based in Budapest, Hungary, which liaises with Chinese scholars traveling to CEE, conducts research, organizes conferences, invites contributions by $\mathrm{CEE}$ authors, and funds research projects of CEE think tanks. The 16+1TTN, which will be discussed below, is coordinated by CASS, while researchers from other Institutes within CASS (i.e., Sociology, World Economics, History, etc.) have also picked up greater interest in the region.

The study of CEE at CASS has undergone different stages, which illustrate changes in the meaning of CEE for the Chinese policy process. Originally, CEE belonged to the portfolio of IEERCAS, which conducted area studies of socialist countries in Eurasia, and subsequently focused on the systemic transformations in CEE after the fall of state socialism. By 2004, when eight CEE countries became EU members, research on CEE was incorporated to the IES, which had previously focused primarily on Western Europe. With the launch of $16+1$ and the BRI, CASS now studies CEE predominantly from the perspective of China's pro-active diplomacy and the BRI. The Department of CEE Studies at IES has the most direct link to policy-making as its members regularly participate in coordination meetings at the 16+1 Secretariat at MoFA.

There are a number of other Chinese think tanks and research institutions that now work on CEE, such as the China Institutes for International Studies (CIIS) and Shanghai Institutes for International Studies (SIIS), while area studies centers have been established at Shanghai University of International Business and Economics (SUIBE), Tongji University, Capital Normal University (CNU), Beijing Foreign Studies University (BFSU), and others. Some of the largest gatherings of policymakers and scholars in China, such as the annual Shanghai Forum, now regularly host sessions on CEE. As they started closing the knowledge gaps and established linkages with their counterparts from the region, Chinese think tanks encountered a social space for think tanks profoundly different from those existing within China.

\section{CEE think tanks}

Think tanks in CEE are commonly considered a type of non-governmental (NGO) or civil society organization (CSO) that played an instrumental role in the process of postsocialist transformation in CEE. They "were created to provide intellectual and political muscle for the transition taking place" (McGann and Weaver as cited in Medzihorský (2007)), and have been "perceived as appliers and adapters of external paradigms" in

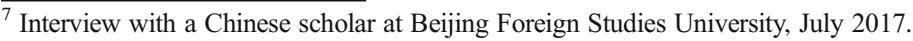


the region (Barani and Sciortino 2011, p. 14). CEE think tanks have established linkages with their counterparts in neighboring countries, but first and foremost with influential actors in the West. The goal was to translate (neo)liberal norms, policies, and practices, and to defend them when threatened, leading Krastev (1999) to call CEE think tanks the "liberal estate." This also allowed CEE think tanks to attract financial and non-financial support to carry out their mission within the framework of the democracy promotion paradigm (Medzihorský 2007). In terms of their ability to influence the policy process via evidence-based research, they have noted mixed success, with ample room for improvement (Buldioski 2012).

Nevertheless, in addition to non-governmental think tanks, in some of the countries in CEE there are well-established government-affiliated think tanks, most notably in the area of foreign policy, whose background and line of work are different compared with the mainstream (neo)liberal think tanks. There are also research institutes affiliated to universities and institutes enjoying some other form of public status that perform roles commonly associated with think tanks. This has been especially visible in the interaction with China - while the common understanding of the think tanks in the region has been the liberal one (i.e., think tanks as NGOs), the composition of knowledge actors working on, and in particular, cooperating with China under the think tank label, has been more varied. According to the official report on the work of the $16+1$ TTN in 2015-2016, the highest number of partner organizations in the network are governmental think tanks, followed by universities and other research institutions, while nongovernmental think tanks have the smallest share (Liu et al. 2017, p. 8).

\section{CEE think tanks working on China}

Historically, China was not a priority for CEE think tanks. However, with the advancement of the BRI and $16+1$, the social space of think tanks working on China is becoming increasingly vibrant. It is inhabited by both non-governmental and government-affiliated organizations as well as free-floating individuals, with notable variations of how this social space has developed in different countries. For example, Poland and the Czech Republic have a growing scene of area studies institutes and foreign policy think tanks who work on China; while in countries like Montenegro or Albania there are only a handful of scholars familiar with China.

The most active CEE knowledge actors within the 16+1TTN in the period 20152016, in a report published by the network, are the Latvian Institute for International Affairs (LIIA); the Institute of International Politics and Economics (IMPP) from Serbia; the Polish Institute of International Affairs (PISM); the University of Ljubljana, Slovenia; and EURISC Foundation from Romania (Liu et al. 2017, pp. 6-7). ${ }^{8}$ There are of course many other think tanks who work on and cooperate with China within and beyond the $16+1$ channels, and think tanks who do not necessarily have significant institutionalized cooperation with their Chinese counterparts, but have nonetheless made significant contribution to the knowledge production on Global China, such as the Institute for Eastern Studies (OSW) from Poland or the Association for International

\footnotetext{
${ }_{8}^{8}$ The list also includes several CEE embassies in Beijing who have contributed to think tank exchanges. The highest ranked one is the Embassy of Poland.
} 
Relations (AMO) from the Czech Republic. The latter has also initiated a transnational platform for cooperation and coordination of observers of China's activities in CEE.

The individuals from CEE who work on China are scholars who roam between academic and policy research, former policymakers and retired diplomats, and various opportunity seekers whose trajectories of studying China are immensely varied. In terms of their experience, there are long-time students of China, and researchers who deal with China "in passing." Independently of their experience, however, they have followed different intellectual pathways that inform different normative positions. In this sense, one could discern between three ideal types of CEE researchers working on China: insiders, or those with the most extensive familiarity and connection with China, who predominantly pursue constructive cooperation; affiliates, or those that have gradually developed contact with China in order to pursue more in-depth research; and critics, or those that advocate cautious and vigilant approach toward China. In reality, of course, rarely do actors have a clear-cut position, and some of them change their position over time.

\section{Cooperation of Chinese and CEE think tanks}

In recent years, China-CEE relations have developed through a number of channels, the most prominent one being the $16+1$ platform, which has served both as a leg and a laboratory for the BRI. $16+1$ has raised a number of questions about the purpose, methods, and effectiveness of China's pro-activeness overseas (see Introduction to this issue). Through 16+1 and the BRI, China has had mixed economic achievements and has not inspired a major power shift in CEE (Pavlićević 2019); nevertheless, it has left its imprint in the region, not least by exercising symbolic power (Vangeli 2018b).

According to the Chinese Ministry of Foreign Affairs (MoFA), people-to-people exchanges, including interactions of think tanks, are considered some of the main achievements of 16+1 (PRC MoFA 2017). Since the onset of the 16+1 in 2012, one of the venues of advancing the cooperation is the High-Level Think Tanks Symposium. To date, there have been five such symposia, convened separately from the $16+1$ Summit of heads of government, held in Beijing in 2013, 2015, and 2017; Bred, Slovenia, in 2014; and Skopje, Macedonia, in 2018. The official calendar of events accompanying the Summits of heads of governments includes annual Think Tanks Forums which have taken place to date in Riga, Latvia, in 2016; Budapest, Hungary, in 2017; Sofia, Bulgaria, in 2018; and Zagreb, Croatia, in 2019.

While Chinese and CEE think tanks have had overall increased cooperation activities that have taken various formats, the $16+1 \mathrm{TTN}$ emerged as a central mechanism for regular coordination, cooperation, and exchange of the above listed official events, and an array of other activities. The Network was first officially announced in the MediumTerm Agenda of 16+1 (PRC MoFA 2015a) and in the Suzhou Guidelines following the 2015 16+1 Summit, as a "network of exchange and cooperation" (PRC MoFA 2015b), although as an idea it existed well before that. Originally announced as a Center, and later reconceptualized as a Network (Liu 2015), the institution was expected to facilitate the formation of an intellectual community, to take over some of the logistics functions of the Chinese MoFA in terms of coordination of "Track 2" and "Track 1.5" diplomacy, develop research projects pertinent to China-CEE relations, and survey public 
perceptions. The $16+1 \mathrm{TTN}$ was officially launched during the Third High-Level Think Tanks Symposium held in Beijing in December 2015. In the period 2015-2018, 16+1TTN operated at a high pace, organizing numerous events, exchanges, and publishing several edited volumes featuring articles by both Chinese and CEE scholars (Liu et al. 2017). The official website lists partnerships between CASS and more than 80 research organizations from all the sixteen CEE countries (China-CEEC Think Tanks Network 2019).

The raison d'etre of knowledge networks established by think tanks is to achieve policy and societal impact (Stone 2013, pp. 39-42). Yet, subjective assessments of the impact of the 16+1TTN are ambiguous. Some interviewees from CEE argued that the $16+1$ TTN exchanges are still a fringe sociopolitical development in CEE, with little relevance and impact, while others have praised them as a bridge-building activity. Chinese interlocutors have been more enthusiastic, emphasizing the people-to-people purpose of think tank interactions; they have also been more confident about their own role in the policy process in China. Some critical Chinese and CEE voices have argued that the emphasis on people-to-people exchanges, and thus the investment in think tank exchanges, is a way to compensate for, as they perceive it, the not-so-stellar economic achievements of $16+1$. For others, think tank cooperation is a useful way to formulate new policy approaches that would help in unlocking the economic potential. Some external observers, on the other hand, see China's new pro-active role in CEE, including the cooperation of think tanks, as a threat to the liberal agenda in the region (Benner et al. 2018).

At the same time, in the words of senior Chinese scholars, the $16+1 \mathrm{TTN}$ is to a great extent a process of "learning by doing"; overall, from the perspective of China's foreign policy, it is seen as comprised of two novelties: it is a new type of mechanism (inclusive network; as never before have Chinese institutions been so open to so many participants) and a new platform (sublevel of official communication; or rather "Track 2" diplomacy). ${ }^{9}$ This also makes the $16+1$ TTN relevant beyond CEE - it is one of the first mechanisms that facilitate China's emergence as an ideational power in the world. Knowledge networks in CEE (and beyond) have been predominantly led by both public and private Western actors, and in this sense, the China-CEE think tank cooperation is an important intervention in that landscape.

\section{The Network from within}

$16+1$ TTN is an asymmetrical form of interaction, which is initiated, founded, predominantly funded, and managed by Chinese institutions, but is well utilized by CEE participants for their own goals. It overall provides new communication infrastructure for Chinese and CEE knowledge actors, which helps them quickly fill the gaps left behind by the period disconnect between the two sides in the post-1989 era (Wasserstrom 2000). The frequent visits to China organized for CEE scholars have a dense agenda, involving long conferences, seminars, lectures, discussions, and field trips. They have also provided CEE participants with embodied experiences including travel on Chinese high-speed trains and visits to sites of techno-scientific and architectural excellence. These excursions have

\footnotetext{
${ }^{9}$ These points were raised at the margins at the Fifth High-Level Think Tanks Symposium of China and CEE in Skopje, October 2018.
} 
co-shaped the subjective lessons that individuals, and in particular newcomers, draw from their (first) China experiences. ${ }^{10}$ Visits by Chinese actors to various CEE countries have been less rich in content, but nevertheless helping shape the way in which Chinese scholars experience the region, while also helping participants from various CEE countries to expand their knowledge of their own region as well.

The observed activities of the 16+1TTN featured a core organizational group of Chinese scholars, Chinese scholars who were invited as guests, and a group of scholars from the participant CEE countries. While there were no visible rules of the selection process, candidates were chosen from a limited pool of participants and some of the interlocutors suggested the selection was based on convenience, and often following a snowball technique. ${ }^{11}$ Some participants have been also selected via competitive calls for papers. CEE scholars who joined China-CEE think tank exchanges hold positions across the full spectrum of academic career stages and traverse different fields, i.e., academia, public service, and private consulting. The participants in the $16+1$ TTN have over time developed a sense of community as they frequently meet and interact within the context of 16+1TTN and beyond. This has been lauded as the major contribution of the network (Stec 2018).

The recurring set of actors have articulated a recurring set of tropes of China-CEE cooperation. Despite the variation in the official theme, the observed activities in general were described by CEE participants as somewhat redundant and overly selfreflexive. ${ }^{12}$ On one hand, this suggests that China-CEE think tank cooperation is still in a stage where the different actors are getting accustomed to each other, and even more so, that they have struggled to produce deeper analytical insights. On the other, these interactions have nonetheless increased the level of inter-subjectivity between the two sides, helping to forge a common future orientation and create a sense of shared goals, articulating the "desire for more" and better cooperation of both sides. Through the increased interaction, there has also been a significant boost in the co-production of knowledge through joint workshops, collective publications, and collaborative research projects. All of these endeavors have also served to further advance the intersubjectivity of Chinese and CEE participants and develop an idiosyncratic, albeit eclectic, common 16+1 policy discourse, that enables diffusion.

\section{Diffusion process in action}

Since the onset of the interaction with CEE, the dominant framework within the 16+ 1TTN was one of pragmatic, somewhat apolitical, "win-win" cooperation. Adapting to this frame, CEE participants developed their own constructive approach toward the cooperation, which portrayed China as a powerful economic actor that can contribute to

\footnotetext{
${ }^{10}$ There have also been a number of other embodied experiences, which have helped in producing the subjective images of China, such as the physical sensations that the China trip offers (jet lag, local cuisine, humid (and sometimes polluted) air, crowds), which, I have discovered, are also significant for the ideational impact I analyze in this article. Of course, embodied experiences are not unique to China-led interactions, but the particularity of how CEE participants have imagined, experienced, and interpreted their China experience has stood out during my research.

${ }^{11}$ Interview with a CEE scholar (A), Budapest, April 2018.

12 This point was particularly discussed during the Fifth High-Level Symposium in Skopje, October 2018.
} 
the economic development of the region. ${ }^{13}$ As the two frames have aligned, the Chinese and the CEE actors downplayed existing and potential frictions at the global stage, creating a safe, desecuritized (see Jakimow in this issue) context in which scholars made contemplated policy ideas. This context assumed of a peaceful world where different actors freely cooperate, paradoxically helping in the diffusion of a worldview that approximates some of the principles of International Relations liberalism.

The frames developed by CEE scholars were not solely a response to the Chinese pro-activity in the region, nor have they only considered the economic common sense of cooperation with China. Many CEE scholars were, for example, first attracted to the idea of working with China by reading Anglophone literature on China's economic miracle, taking experienced Western "China hands" as role models, ${ }^{14}$ and perceived, in the new interactions with their Chinese counterparts, a source of legitimacy ${ }^{15}$ and emancipation on the global stage. This approach, however, has been quite distinct from one of the main Chinese frames, which sought to portray CEE as part of the Global South (Kowalski 2017) and as a bridge between the East and the West. At the same time, while rejecting the South-South rhetorical frame, in contemplating the future steps of cooperation, many Chinese scholars have essentially supported a South-South action frame, i.e., by accepting policy ideas that had been originally devised in China's relations with developing countries ${ }^{16}$ - not the least because of the enticement of the new geoeconomic imaginaries deployed by China.

Actively imagining win-win outcomes of the integration CEE in the New Silk Roads are part and parcel of the China-CEE think tank cooperation experience. Discussions have often revolved around the construction of megaprojects such as high-speed rails, highways, and waterways; investing in energy and industrial capacities; developing new technologies, and tapping into the various potentials of China and CEE. With the exception of discussions of ongoing or pre-planned projects, these desired outcomes were not based on current realities, but rather on the capacity of the actors to imagine a different and, oftentimes, more promising future. This future was not always imagined through projecting new ideas and desires, but also by reviving old ones that had never materialized, e.g., projects to build a waterway from Danube to the Aegean or to invigorate the Polish Amber Road (Dimitrijević 2016). All of these discussions have contributed to the extensions of the geoeconomic imaginaries among CEE scholars which often had a therapeutic component, especially when contrasting the imagined futures of the New Silk Roads with the subjective experiences of crisis and uncertainty, the legacy of peripherality, and the "race to the bottom"17 under neoliberal globalization (which are admittedly varied across the sixteen countries).

\footnotetext{
13 This has also generated the trope of the high expectations of CEE actors, often heard during 16+1TTN events. In an attempt to tone down the high expectations expressed by their CEE counterparts, one Chinese scholar argued that China's role in 16+1 and BRI should not be seen as "Santa Claus." Participant observation, event in Budapest, July 2018.

${ }^{14}$ Interview with a CEE scholar (B), Belgrade, April 2018.

${ }^{15}$ Interview with a CEE scholar (D), Budapest, April 2018.

${ }^{16}$ It is altogether a different question to what extent the policy outcomes of the South-South frames have been effective (Jakóbowski 2018).

${ }^{17}$ Participant observation, event in Beijing, 2014.
} 
The proliferation of desires such as infrastructural megaprojects and burgeoning capital flows also raises the question of how to rearticulate them as particular policy ideas, turning the diffusion of abstract ideas of economic progress, into diffusion of general guidelines and maxims of economic development, which more often than not are at least partially rooted in the Chinese post-1978 experience. ${ }^{18}$ Thus, through these processes, both Chinese and non-Chinese participants in the $16+$ 1TTN have actively engaged with a number of concepts that may have been originally unfamiliar for the other side. New policy concepts proposed by Chinese actors are a subject of research and debate, and are re-interpreted and adapted (but not merely replicated) by the non-Chinese participants. For example, "production capacity cooperation" (PCC), one of the new keywords of China's economic diplomacy (Qiu 2015), was a subject of a seminar organized by the Network in 2016. By the time of the seminar, most of the CEE participants had little idea what PCC means; nevertheless, they reflected on the topic critically and produced original research; ultimately, the product of those exchanges was the emergence of a new understanding of PCC and the formulation of policy suggestions accordingly. In 2017, the $16+1$ TTN hosted a workshop on framing $16+1$ in the context of the BRI. In the proceedings from the workshop, a number of perspectives have been published (Huang and Liu 2017), all of which formulate ideas how to situate BRI policy ideas in the CEE context.

There are also more prosaic examples of diffusion-as-translation within the work of $16+1$ TTN. Tropes such as "win-win cooperation" or principles such as "if you want to develop, build a road first" or "if you build a road, they will come" that are central in the Chinese policy discourse have been slowly becoming part of the China-CEE discourse, sometimes appropriated by CEE scholars, and rearticulated in ways that make sense to them. At the same time, the processes of ideational diffusion have also taken the opposite direction: for example, throughout the think tank exchanges, Chinese scholars have adopted concepts on the primacy of the norms and rules of the European Union (EU) in CEE (in part also adressing the criticism expressed by some observers that through $16+1$ China subverts the EU). In the process, however, the interpretation and localization of this idea by the Chinese actors have been undertaken primarily in accord with their own knowledge and interests. Such developments may be seen as being in line with the goal of Chinese think tanks to contribute to the transformation, or rather adaptation, of Chinese institutions to make them "compatible with the requirements of global capital" (Hayward 2018, p. 46), although there are grounds to interpret this conversely as a success of the CEE participants in reversing the flow of diffusion.

\section{Concluding remarks}

As a result of China's pro-activity in the era of the BRI, the cooperation between Chinese and CEE think tanks intensified and became regularized over a short period of time. This development was unexpected and counter-intuitive, as

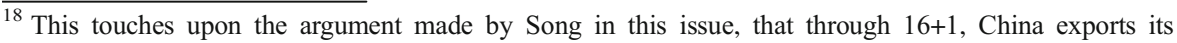
developmental state model.
} 
Chinese and CEE think tanks were different types of actors with little contact in the period 1989-2010s. The $16+1$ TTN is thus an example of the innovation of China's new ("Track 2") diplomacy in the era of the BRI-bringing to reality what "no one could have possibly imagined" before. ${ }^{19}$ The $16+1$ TTN already has a life of its own, and has contributed to the creation of a vibrant epistemic community of China-CEE scholars. Through dialogical (albeit asymmetrical) coproduction of meanings, the think tank interaction helped in the alignment of frames to produce an exceptionally constructive context, in the extension of the geoeconomic imaginaries and their accompanying normative sets by proliferating narratives of (imagined) economic successes, and in the translation of policy concepts that originate in China's developmental experience.

There are two important caveats to this analysis. First, the analysis focused primarily on the interaction of Chinese and CEE think tanks in its own context, thus capturing aspects of ideational impact within the knowledge network itself but not beyond it (that would be in the interactions within the societies at large in which think tanks are to play a particular role, and the interactions between think tanks and policymakers). In the words of CEE scholars, this knowledge network in the regional context of CEE still does not represent "critical mass" 20 and cannot yet have significant impact.

Second, the analysis zoomed in on one aspect of China-CEE relations under the BRI. Nevertheless, China-CEE relations do not develop in isolation but are increasingly contested by actors who have more significant political and economic leverage than China in CEE, including the current US administration under President Trump and some actors in the EU. This has also brought a new impulse in the Western-led knowledge networks and civil society infrastructures of which CEE think tanks have been historically part of, which now increasingly deal with China's influence and interference around the world, including in CEE. The new developments generate counter-frames and create new conditions of openly competing ideas.

Nevertheless, what work to sustain the framework of the BRI and $16+1$ are the potent geoeconomic imaginaries, and their normative load, that ultimately drive the process of diffusion. The diffusion of policy ideas in the China-led formats is inseparable from the narratives of economic greatness, the images of trains and container ships, and the cartography of the new corridors and hubs of the New Silk Roads. The policy ideas diffused through the BRI, therefore, despite being normative in nature, are not driven through normative logic, but rather by the promise of economic development.

Acknowledgments The author wishes to thank their interviewees for the information provided, and Dragan Pavlićević, Vasilis Trigkas, Michael Gow, and the two reviewers for helping improve the article. The author has been a non-resident fellow with the China-CEE Institute in Budapest and a visiting fellow at the Institute for International Relations in Prague, has cooperated with other think tanks in CEE and beyond, including the Turin World Affairs Institute, and has actively taken part in the 16+1 Think Tank Network and the network China Observers in Europe (CHOICE), all of which have informed their understanding of the topic at hand.

Funding information In conducting this research, the author has in part benefited from a fieldwork grant awarded by the French Center on Contemporary China (2014); a Claussen-Simon PhD Fellowship of the

\footnotetext{
${ }^{19}$ Interview with a CEE scholar (E), Budapest, June 2018.

${ }^{20}$ Participant observation, event in Sofia, June 2018.
} 
Trajectories of Change Program, ZEIT-Stiftung Ebelin und Gerd Bucerius (2015-2018); a Civil Society Scholar Award of the Open Society Foundations (2018); and a doctoral dissertation completion grant of the Chiang Ching-kuo Foundation (2018-2019).

Open Access This article is distributed under the terms of the Creative Commons Attribution 4.0 International License (http://creativecommons.org/licenses/by/4.0/), which permits unrestricted use, distribution, and reproduction in any medium, provided you give appropriate credit to the original author(s) and the source, provide a link to the Creative Commons license, and indicate if changes were made.

\section{References}

Andornino GB (2017) The Belt and Road Initiative in China's emerging grand strategy of connective leadership. China World Econ 25:4-22. https://doi.org/10.1111/cwe.12211

Barani L, Sciortino G (2011) The role of think tanks in the articulation of the European public sphere. Eurosphere Comp Stud 10:16

Beckert J (2016) Imagined futures. Harvard University Press

Béland D (2009) Ideas, institutions, and policy change. J Eur Public Policy 16:701-718. https://doi. org/10.1080/13501760902983382

Benabdallah L (2017) Explaining attractiveness: knowledge production and power projection in China's policy for Africa. J Int Relat Dev 22:495-514. https://doi.org/10.1057/s41268-017-0109-x

Benner T, Gaspers J, Ohlberg M, et al (2018) Authoritarian advance: responding to China's growing political influence in Europe. Global Public Policy Institute and the Mercator Institute for China Studies

Bourdieu P (1979) Symbolic power. Crit Anthropol 4:77-85. https://doi.org/10.1177/0308275X7900401307

Breslin S (2011) The 'China model' and the global crisis: from Friedrich List to a Chinese mode of governance? Int Aff 87:1323-1343. https://doi.org/10.1111/j.1468-2346.2011.01039.x

Buldioski G (2012) Think tanks in Central and Eastern Europe and the quality of their policy research. Studiorum, Skopje

Campbell JL (2002) Ideas, politics, and public policy. Annu Rev Sociol 28:21-38. https://doi.org/10.1146 /annurev.soc.28.110601.141111

Cao D (2019) President calls on think tanks to boost teamwork, Belt, Road construction. China Dly

Capie D (2010) When does track two matter? Structure, agency and Asian regionalism. Rev Int Polit Econ 17: 291-318. https://doi.org/10.1080/09692290903378801

China-CEEC Think Tanks Network (2019) Partners. In: China-CEEC Think Tanks Netw. http://16plus1thinktank.com/en/6/index.jhtml. Accessed 28 May 2019

China-CELAC Forum (2015) Forum of interchange between China-Latin America and the Caribbean think tanks. In: China-CELAC Forum. http://www.chinacelacforum.org/eng/zyjz_1/zylyflt/zlzkjllt/t1278803. htm. Accessed 12 Mar 2019

Dimitrijević D (ed) (2016) Danube and the New Silk Road. Institute for International Politics and Economics, Belgrade

Dobbin F, Simmons B, Garrett G (2007) The global diffusion of public policies: social construction, coercion, competition, or learning? Annu Rev Sociol 33:449-472. https://doi.org/10.1146/annurev. soc.33.090106.142507

Emewu I (2018) Seventh China-Africa Think Tanks Forum holds in Beijing. In: Afr. CHINA Econ. https://africachinapresscentre.org/2018/07/04/seventh-china-africa-think-tanks-forum-holds-in-beijing/. Accessed 14 Dec 2018

Gilardi F (2013) Chapter 18: transnational diffusion: norms, ideas, and policies. In: Handbook of international relations. SAGE

Hayward J (2018) The rise of China's new-type think tanks and the internationalization of the state. Pac Aff 91:27-47. https://doi.org/10.5509/201891127

Huang P, Liu Z (eds) (2017) How the 16+1 cooperation promotes the Belt and Road Initiative, China-CEEC think tanks book series. China Social Sciences Press

Jakóbowski J (2018) Chinese-led regional multilateralism in Central and Eastern Europe, Africa and Latin America: $16+1$, FOCAC, and CCF. J Contemp China 27:659-673. https://doi.org/10.1080 $/ 10670564.2018 .1458055$ 
Kavalski E (2013) The struggle for recognition of normative powers: normative power Europe and normative power China in context. Coop Confl 48:247-267. https://doi.org/10.1177/0010836713485386

Kowalski B (2017) China's foreign policy towards Central and Eastern Europe: the "16+1" format in the South-South cooperation perspective. Cases of the Czech Republic and Hungary. Camb J Eurasian Stud 1:7R65ZH. https://doi.org/10.22261/7R65ZH

Krastev I (1999) The liberal estate: reflections on the politics of think tanks in Central and Eastern Europe. East Cent Eur 26:35-53. https://doi.org/10.1163/187633099X00031

Ladi S (2000) Globalisation, think tanks and policy transfer. In: Stone D (ed) Banking on knowledge: the genesis of the global development network, London, Routledge. Routledge, London; New York

Lendvai N, Stubbs P (2007) Policies as translation: situating transnational social policies. In: Hodgson SM, Irving Z (eds) Policy reconsidered: meanings, politics and practices. Policy Press, Bristol, U.K, pp 173190

Li C (2017) The power of ideas: the rising influence of thinkers and think tanks in China. World Scientific

Li HY, Wong S (2018) The evolution of Chinese public diplomacy and the rise of think tanks. Place Brand Public Dipl 14:36-46. https://doi.org/10.1057/s41254-017-0090-6

Li X, Brødsgaard KE, Jacobsen M (2010) Redefining Beijing consensus: ten economic principles. China Econ J 2:297-311. https://doi.org/10.1080/17538960903529535

Liu Z (2015) China's “One Belt One Road” strategy: a successful story that the think tank has done

Liu Z, Ju W, Ma J (2017) The development and evaluation report of China-CEEC think tanks exchange and cooperation (2015-2016), China-CEEC think tanks book series. China Social Sciences Press

Lukes S (2007) Power and the battle for hearts and minds: on the bluntness of soft power. In: Berenskoetter F, Williams MJ (eds) Power in world politics. Routledge, London ; New York, pp 83-97

Mayer M (ed) (2017) Chapter 1: China's rise as Eurasian power: the revival of the Silk Road and its consequences. In: Rethinking the Silk Road: China's Belt and Road Initiative and emerging Eurasian relations. Palgrave Macmillan, New York, NY, pp 1-42

McGann JG (2010) Democratization and market reform in developing and transitional countries think tanks as catalysts. Routledge

Medzihorský J (2007) A new grey zone: intellectuals, think tanks, and politics in post-communist Slovakia. MA thesis at the Central European University

Menegazzi S (2017) Rethinking think tanks in contemporary China. Springer

Parsons T (1963) On the concept of influence. Public Opin Q 27:37-62

Pavlićević D (2019) A power shift underway in Europe? China's relationship with Central and Eastern Europe under the Belt and Road Initiative. In: Li X (ed) Mapping China's "One Belt One Road" Initiative. Palgrave

Plehwe D, Walpen BJA, Neunhöffer G (2007) Neoliberal hegemony: a global critique. Routledge

PRC MoFA (2015a) The medium-term agenda for cooperation between China and Central and Eastern European countries

PRC MoFA (2015b) The Suzhou Guidelines for Cooperation between China and Central and Eastern European Countries

PRC MoFA (2017) Five-year outcome list of cooperation between China and Central and Eastern European countries

Qiu Z (2015) The 'triple win': Beijing’s blueprint for international industrial capacity cooperation. China Brief 15

Scott JM (1999) Transnationalizing democracy promotion: the role of Western political foundations and thinktanks. Democratization 6:146-170. https://doi.org/10.1080/13510349908403625

Shambaugh D (2013) China goes global: the partial power. Oxford University Press

Stec G (2018) 16+1 cooperation and the Belt \& Road in Central and Eastern Europe. Voices Belt Road

Stone D (2013) Knowledge actors and transnational governance: the private-public policy nexus in the global agora. Springer

Swedberg R (2011) The economic sociologies of Pierre Bourdieu. Cult Sociol 5:67-82. https://oi. org/10.1177/1749975510389712

Taylor C (2002) Modern social imaginaries. Public Cult 14:91-124. https://doi.org/10.1215/08992363-14-191

Vangeli A (2017) China's engagement with the sixteen countries of Central, East and Southeast Europe under the Belt and Road Initiative. China World Econ 25:101-124. https://doi.org/10.1111/cwe.12216

Vangeli A (2018a) The normative foundations of the Belt and Road Initiative. In: Shan W, Nuotio K, Zhang K (eds) Normative readings of the Belt and Road Initiative. Springer, Cham, pp 59-83

Vangeli A (2018b) Global China and symbolic power: the case of 16+1 cooperation. J Contemp China 27:. https://oi.org/10.1080/10670564.2018.1458056 
Vangeli A (2019) A framework for the study of the One Belt, One Road Initiative as a medium of principlediffusion. In: Li X (ed) Mapping China’s “One Belt One Road” Initiative. Palgrave

Wasserstrom J (2000) Chinese bridges to postsocialist Europe. In: Antohi S, Tismaneanu V (eds) Between past and future: the revolution of 1989 and their aftermath. Central European University Press, pp 357-382

Weyland K (2009) Bounded rationality and policy diffusion: social sector reform in Latin America. Princeton University Press

Yu J (2018) The belt and road initiative: domestic interests, bureaucratic politics and the EU-China relations. Asia Eur J 16:223-236. https://doi.org/10.1007/s10308-018-0510-0

Zhao Q (2006) Epistemic community, intellectuals, and Chinese foreign policy. Polic Soc 25:39-59. https://oi.org/10.1016/S1449-4035(06)70126-6

Zhu X (2017) Think tank management system in China. East Asian Policy 09:92-99. https://doi.org/10.1142 /S1793930517000198

Publisher's note Springer Nature remains neutral with regard to jurisdictional claims in published maps and institutional affiliations. 